\title{
PENERAPAN PEMBELAJARAN BERBASIS MASALAH BERBANTUAN PROGRAM GEOMETER'S SKETCHPAD UNTUK MENINGKATKAN KEMAMPUAN REPRESENTASI MULTIPEL MATEMATIS SISWA
}

\author{
Depi Ardian Nugraha \\ Pendidikan Matematika, FKIP, Universitas Galuh Ciamis \\ e-mail:depiatb@gmail.com
}

\begin{abstract}
ABSTRAK
Pentingnya kemampuan representasi multipel matematis bagi siswa telah banyak disadari dalam pendidikan matematika. Namun masih minimnya cara yang dapat digunakan dalam meningkatkan kemampuan tersebut, menjadi ide dasar dilaksanakannya penelitian ini. Melalui penerapan pembelajaran berbasis masalah berbantuan program Geometer's Sketchpad (GSP) diharapkan dapat memperkaya strategi dalam meningkatkan kemampuan representasi multipel matematis siswa. Penelitian ini bertujuan untuk mendeskripsikan dan membandingkan peningkatan kemampuan representasi multipel matematis siswa yang memperoleh pembelajaran berbasis masalah berbantuan program Geometer's Sketchpad, pembelajaran berbasis masalah tanpa bantuan program Geometer's Sketchpad, dan pembelajaran konvensional, membandingkan peningkatan kemampuan representasi multipel matematis siswa yang memperoleh penerapan pembelajaran berbasis masalah berbantuan program Geometer's Sketchpad lebih baik daripada siswa yang memperoleh pembelajaran berbasis masalah tanpa bantuan program Geometer's Sketchpad dan pembelajaran konvensional dilihat dari kemampuan awal matematika (unggul,asor). Penelitian ini termasuk penelitian quasi eksperimen dengan desain kelompok kontrol tidak ekuivalen. Penelitian ini dilakukan di SMPN 10 Tasikmalaya, dengan subjek populasi seluruh siswa kelas VII SMPN 10 Tasikmalaya dan mengambil tiga sampel kelas VII SMPN 10 Tasikmalaya secara purposive sampling. Instrumen yang digunakan meliputi soal tes kemampuan representasi multipel matematis. Analisis data kuantitatif menggunakan uji ANOVA satu dan dua jalur, dilanjutkan dengan uji Scheffe. Berdasarkan hasil penelitian dapat disimpulkan bahwa terdapat perbedaan yang signifikan peningkatan kemampuan representasi multipel matematis siswa antara yang memperoleh pembelajaran PDG, pembelajaran PTG, dan pembelajaran KV secara keseluruhan. Dilihat dari kemampuan awal matematika (unggul, asor), secara signifikan peningkatan kemampuan kemampuan representasi multipel matematis siswa yang memperoleh pembelajaran PDG tidak lebih baik dari PBL dan peningkatan representasi multipel matematis siswa yang memperoleh pembelajaran PDG lebih baik dari pembelajaran KV dan yang memperoleh PTG lebih baik dari pada pembelajaran KV
\end{abstract}

Kata kunci: Pembelajaran Berbasis Masalah (PBL), Geometer's Sketchpad, Pembelajaran PBL dengan Menggunakan Geometer's Sketchpad (PDG), Pembelajaran PBL tanpa Menggunakan Geometer's Sketchpad (PTG), Pembelajaran Konvensioanal (KV), Kemampuan Representasi Multipel Matematis 


\section{PENDAHULUAN}

Pembelajaran matematika di sekolah memiliki peranan penting dalam mengembangkan kemampuan matematis siswa. Menurut Suryadi (2013: 37) mengungkapkan bahwa ada berbagai kemampuan yang bisa dikembangkan melalui matematika. Kemampuan tersebut dapat berkontribusi pada tiga dimensi kebutuhan anak yakni untuk melanjutkan pendidikan pada jenjang yang lebih tinggi, digunakan dalam kehidupan sehari-hari di lingkungan masyarakat, atau untuk menunjang kebutuhan yang berkaitan dengan pekerjaan.

Berdasarkan pendapat Suryadi dapat disimpulkan bahwa seseorang setelah belajar matematika bukan hanya untuk mengembangkan kemampuan matematisnya saja, tetapi diharapakan dapat digunakan untuk kebutuhan hidupnya dimasa yang akan datang, baik dalam kehidupan sehari-hari atau untuk melanjutkan pendidikan ke jenjang yang lebih tinggi. Menurut Kemendikbud (2013) dalam Standar isi Kurikulum 2013 menyebutkan bahwa tujuan pembelajaran matematika di Sekolah yaitu agar siswa memiliki kemampuan sebagai berikut: 1) melatih cara berpikir dan bernalar dalam menarik kesimpulan, misalnya melalui kegiatan penyelidikan, eksplorasi, eksperimen, menunjukkan kesamaan, perbedaan, konsistensi dan inkonsistensi, 2) mengembangkan aktivitas kreatif yang melibatkan imajinasi, intuisi, dan penemuan dengan mengembangkan pemikiran divergen, orisinil, rasa ingin tahu, membuat prediksi dan dugaan, serta mencoba-coba, 3) mengembangkan kemampuan memecahkan masalah, dan 4) mengembangkan kemampuan menyampaikan informasi atau mengkomunikasikan gagasan antara lain melalui pembicaraan lisan, grafik, peta, diagram, dalam menjelaskan gagasan.

Demikian pula halnya tujuan yang diharapkan dalam pembelajaran matematika oleh National Council of Teacher Mathematics (NCTM, 2000) menetapkan bahwa terdapat 5 keterampilan proses yang perlu dimiliki siswa melalui pembelajaran matematika yang tercakup dalam standar proses tersebut, yaitu: " (1) problem solving; (2) reasoning and proof; (3) communication; (4) connection; dan (5) representation". Kemampuan-kemampuan tersebut termasuk pada berpikir matematika tingkat tinggi ( high order mathematical thinking) yang harus dikembangkan dalam proses pembelajaran matematika.

Berdasarkan kompetensi-kompetensi pembelajaran matematika yang harus dicapai siswa baik yang tertuang dalam KTSP maupun NCTM, nampak bahwa kemampuan pemecahan masalah dan kemampuan representasi multipel matematis merupakan aspek penting dalam pembelajaran matematika. Hanya saja istilah representasi dalam Kurikulum 2013 disebutkan dalam kalimat "mengembangkan kemampuan menyampaikan informasi atau mengkomunikasikan gagasan antara lain melalui pembicaraan lisan, grafik, peta, diagram, dalam menjelaskan gagasan".

Umumnya sistem pembelajaran yang digunakan adalah sistem pembelajaran tempo dulu yaitu sistem pembelajaran yang kurang mendukung siswa untuk meningkatkan kemampuan pemecahan masalah dan representasi multipel matematis. Dalam proses belajar mengajar, guru mendominasi kegiatan pembelajaran dan peserta didik hanya duduk, mendengar, mencatat menghapal mengenai materi yang diberikan, melihat contoh soal yang diberikan dan penyelesaiannya setelah itu siswa disuruh mengerjakan soal sesuai dengan contoh yang telah diberikan. Sistem pembelajaran seperti itu hanya bersifat satu arah dan mengakibatkan kurang berkembangnya kemampuan siswa untuk berpikir tingkat tinggi misalnya kemampuan memecahkan masalah dan representasi multipel matematis dalam pembelajaran matematika. Sistem pemebelajaran seperti itu sering disebut pembelajaran konvensional. Hal ini berakibat pula pada rendahnya mutu pendidikan matematika.

$$
\text { Rendahnya mutu pendidikan }
$$
matematika di alami juga di salah satu sekolah di Kota Tasikmalaya, Berdasarkan 
hasil wawancara dengan guru matematika yang bernama Bapak Otto (anonim), berdasarkan pendapat guru tersebut siswa mengalami banyak kesulitan terutama ketika mengerjakan soal untuk mengukur kemampuan tingkat tinggi. Salah satunya yaitu soal untuk mengukur kemampuan pemecahan masalah dan representasi matematis, dari jumlah siswa yang ada hanya sekitar 35\% yang mampu melebihi dari kriteria yang ditentukan.

Pentingnya pemecahan masalah matematis ditegaskan dalam National Council of Teachers of Mathematics (NCTM, 2000:52) yang menyatakan bahwa pemecahan masalah merupakan bagian integral dalam pembelajaran matematika, sehingga hal tersebut tidak boleh dilepaskan dari pembelajaran matematika. Pendapatpendapat tersebut menyatakan bahwa kemampuan pemecahan masalah matematis sangatlah penting. Oleh karena itu kemampuan seseorang dalam memecahan masalah matematis perlu terus dilatih sehingga orang tersebut mampu menyelesaikan berbagai permasalahan yang dihadapinya.

Kemampuan pemecahan masalah matematis sangat erat hubungannya dengan kemampuan representasi matematis. Konstruksi representasi matematis yang tepat akan memudahkan siswa dalam melakukan pemecahan masalah. Suatu masalah yang rumit akan menjadi lebih sederhana jika menggunakan representasi yang tepat.

NCTM, (2000: 67) menyebutkan “ representasi yang dimunculkan oleh siswa merupakan ungkapan- ungkapan dari gagasan-gagasan atau ide-ide matematis yang ditampilkan siswa dalam upayanya untuk mencari suatu solusi dari masalah yang sedang dihadapinya". Cai, Lane dan Jacabsin (Shadiq, 2004:6) memandang representasi "sebagai alat yang digunakan seseorang untuk mengkomunikasikan jawaban atau gagasan matematis yang bersangkutan".

Meskipun kemampuan representasi telah dinyatakan sebagai salah satu standar proses dalam Kurikulum 2006 yang harus dicapai oleh siswa melalui pembelajaran matematika, namun dalam pelaksanaan di sekolah umumnya belum sesuai dengan yang diharapkan. Studi pendahuluan pada penelitian yang Hutagaol (2007:8) menyatakan bahwa kurang berkembangnya daya representasi siswa khususnya siswa SMP karena siswa tidak pernah diberi kesempatan untuk melakukan representasinya sendiri, tetapi harus mengikuti apa yang sudah dicontohkan oleh guru yang menyebabkan siswa tidak mampu merepresentasikan gagasan matematis dengan baik.

Selain hal tersebut keterbatasan pengetahuan guru dan kebiasaan siswa belajar di kelas dengan cara konvensional belum memungkinkan untuk menumbuhkan atau mengembangkan daya representasi siswa secara optimal. Hal tersebut sejalan dengan Amri (2009: 4) menyatakan bahwa guru dalam pembelajaran matematika yang berhubungan dengan representasi masih menggunakan cara konvensional, sehingga siswa cenderung meniru langkah guru, siswa tidak pernah diberikan kesempatan untuk menghadirkan kemampuan representasi matematisnya yang dapat meningkatkan kemampuan matematisnya.

Hiebert \& Carpenter (Hudiono, 2005) mengemukakan bahwa kemampuan representasi matematis diajarkan di sekolah karena komunikasi dalam matematika memerlukan representasi matematis yang berupa: simbol tertulis, diagram (gambar), tabel, ataupun benda/obyek. Menurut Jones (Hudiono, 2005) "terdapat beberapa alasan perlunya kemampuan representasi, yaitu: kelancaran dalam membangun suatu konsep dan berpikir matematis ; ide-ide yang diberikan guru sangat mempengaruhi pemahaman siswa dalam matematika; untuk memiliki kemampuan dan pemahaman konsep yang kuat dan fleksibel dapat dibangun melalui kemampuan representasi matematis".

Terdapat beberapa penggolongan mengenai representasi. Akan tetapi pada dasarnya representasi dapat digolongkan menjadi (1) representasi visual (gambar, diagram grafik, atau tabel); (2) representasi simbolik (pernyataan matematis/ notasi matematis, numerik/simbol aljabar); dan 
(3) representasi verbal (teks tertulis/katakata). Penggunaan semua jenis representasi tersebut dapat dibuat secara lengkap dan terpadu dalam pengujian suatu masalah yang sama atau dengan kata lain representasi matematis dapat dibuat secara beragam (multipel representasi).

Geometri adalah materi pelajaran matematika yang membutuhkan kemampuan matematis yang cukup baik dan tinggi untuk memahaminya. Menurut NCTM (Siregar, 2009:5) kemampuan yang harus dimiliki siswa dalam mempelajari geometri adalah 1) kemampuan menganalisis karakter dan sifat dari bentuk geometri baik dua dimensi ataupun tiga dimensi, dan mampu membangun argumen-argumen matematika mengenai hubungan geometri dengan yang lainnya, 2) kemampuan menentukan kedudukan suatu titik dengan lebih spesifik dan gambaran hubungan spasial dengan menggunakan koordinat geometri serta menghubungkannya dengan sistem yang lain; 1) kemampuan aplikasi transformasi dan penggunaannya secara simetris untuk menganalisis situasi matematis, 2) mampu menggunakan visualisasi, penalaran spasial, dan model geometri untuk memecahkan masalah.

Dengan menguasai kemampuankemampuan tersebut, diharapkan penguasaan siswa terhadap materi geometri menjadi lebih baik. Dalam pembelajaran geometri perlu diperhatikan pula peranan alat peraga yang berkaitan erat dengan objek geometri yang abstrak. Ketika teori Van Hiele muncul, jenis alat peraga pembelajaran matematika masih sangat terbatas pada benda-benda kongkrit. Namun, seiring perkembangan teknologi saat ini telah berkembang jenis alat peraga baru yang dikenal dengan konsep alat peraga maya. Alat ini memiliki karakteristik bendabenda semi kongkrit dan dapat dimanipulasi langsung oleh siswa dalam kegiatan. pembelajaran. Contohnya jenis Dynamic Geometry Software (perangkat lunak geometri dinamis).

Geometer's Sketchpad (GSP) adalah software matematis dinamis yang mempelajari geometri, aljabar, kalkulus, dan lain sebagainya. Terdapat beberapa pertimbangan mengenai penggunaan GSP dalam pembelajaran geometri pada siswa SMP. Menurut Hoehn (Lam, 2007) "siswa yang diajarkan geometri dengan GSP dapat membuktikan teorema-teorema yang ada pada geometri". Selanjutnya Villiers (1998) mengatakan " dengan GSP siswa mampu mentransformasi gambar secara dinamis, siswa mampu memeriksa serangkaian kasus serupa dan mengarahkan mereka untuk melakukan generalisasi terhadap sifat-sifat segitiga, segiempat, lingkaran, dan konfigurasi geometris lainnya ". Siswa yang terlibat dalam penggunaan GSP mempunyai kesempatan untuk melihat bentuk yang berbeda dalam konsep-konsep geometri.

Berdasarkan beberapa pendapat di atas, GSP merupakan program matematika dinamis interaktif yang khusus digunakan dalam pembelajaran geometri. Dengan menggunakan GSP dalam pembelajaran geometri siswa dapat mengonstruksi titik, garis, segmen garis, suatu bangun segi- $n$, maupun suatu kurva tertentu yang kemudian dapat di manipulasikan secara dinamis, dan dengan melakukan manipulasi terhadap bentuk-bentuk geometri, mampu membantu siswa dalam proses representasi. Selain itu, pembuktian konsep-konsep geometri pun dapat dibuktikan dengan menggunakan sedikit perhitungan dan manipulasi sederhana.

Upaya yang perlu dilakukan dalam menciptakan pembelajaran untuk meningkatkan kemampuan pemecahan masalah dan representasi matematis adalah dengan memilih model atau strategi pembelajaran yang relavan, salah satunya dengan menerapkan pembelajaran berbasis masalah yang dalam proses pembelajarannnya membelajarkan siswa untuk mengenal masalah, merumuskan masalah, mencari solusi atau menguji jawaban sementara atas suatu masalah/pertanyaan dengan melakukan penyelidikan (menemukan fakta-fakta melalui penginderaan), pada akhirnya dapat menarik kesimpulan dan menyajikannya secara lisan maupun tulisan. Hal tersebut 
sesuai dengan pendapat Stepein (Word,2000) yang menyatakan bahwa pembelajaran berbasis masalah adalah suatu model pembelajaran yang melibatkan peserta didik untuk memecahkan suatu masalah matematis melalui tahapan-tahapan metode ilmiah sehingga peserta didik dapat mempelajari pengetahuan yang berhubungan dengan masalah tersebut dan sekaligus memiliki keterampilan untuk memecahkan.

Selain memilih model pembelajaran yang relevan guru juga harus bisa mengaplikasikan perkembangan teknologi dalam proses pembelajaran agar tugas guru menjadi lebih ringan salah satunya dengan menggunakan bantuan program Geometer's Sketchpad agar dalam proses abstraksi materi, siswa lebih bisa memahami materi yang disampaikan. Memperhatikan uraian di atas, mendorong untuk dilakukan penelitian yang memfokuskan pada penerapan model pembelajaran berbasis masalah berbantuan Program Geometer's Sketchpad untuk meningkatkan kemampuan representasi multipel matematis siswa SMP kelas VII ditinjau dari kemampuan awal matematika siswa.

Terdapat beberapa definisi yang dikemukakan para ahli berkenaan dengan kemampuan representasi matematis, dari beberapa definisi tersebut dapat disimpulkan bahwa representasi multipel atau representasi beragam matematis adalah ungkapan atau ekspresi dari ide-ide matematis yang ditampilkan siswa sebagai hasi dari interpretasi pikirannya, bisa melalui gambar, kata-kata (verbal), tabel, benda konkret, atau simbol matematika sebagai bentuk pengganti, penggambaran, penerjemah dari suatu masalah untuk menemukan solusi dari masalah yang sedang dihadapinya. Suatu masalah dapat direpresentasikan melalui gambar, kata-kata (verbal), tabel, benda kongkrit atau simbol matematika. Kajian representasi beragam matematis atau representasi multipel dapat berupa teks tertulis, grafik, tabel, diagram, gambar, persamaan, ekspresi atau notasi matematis, bahkan wujud konkret.
Pembelajaran berbasis masalah (Problem Based Learning) adalah model pembelajaran yang melatih dan mengembangkan kemampuan berpikir siswa dalam mencari pemecahan masalah melalui pencarian data secara outentik dari kehidupan aktual sehingga diperoleh solusi untuk suatu masalah dengan rasional dan autentik dari kehidupan aktual siswa guna merangsang kemampuan berpikir tingkat tinggi, dengan kata lain siswa lebih diutamakan untuk mengonstruksi sendiri pengetahuannya, sedangkan guru lebih berperan sebagai fasilitator dan motivator.

Pembelajaran Berbantuan Komputer Suatu proses pembelajaran yang dalam pelaksanaannya menggunakan komputer sebagai alat bantu untuk mengajar. Potensi komputer dalam media pembelajaran matematika sangat besar. Melalui software yang sesuai, komputer bisa menjadi alat yang efektif dalam membantu kegiatan pembelajaran matematika. Dengan penggunaan komputer pada proses belajarmengajar, siswa dapat mengeksplorasi sendiri konsep-konsep yang termuat dalam software yang disajikan sehingga guru hanya berperan sebagai fasilitator dalam proses pembelajaran tersebut.

Seiring dengan perkembangan teknologi yang begitu cepat, pembuatan software juga mengalami kemajuan yang pesat. Dewasa ini telah banyak software yang bisa digunakan untuk membuat dan merancang suatu program komputer yang bisa dibuat interaktif ditambah dengan fasilitas multimedia yang lengkap, seperti suara, gambar, animasi, teks, dan video. Perkembangan teknologi seperti ini dapat dimanfaatkan untuk memperbaharui pembelajaran dalam dunia pendidikan, khususnya dalam pembelajaran matematika. Sehingga diharapkan dengan memanfaatkan teknologi multimedia yang berkembang saat ini dapat membantu proses belajar mengajar yang berkesan dan bermakna bagi siswa.

Salah satu alat peraga maya dalam bentuk software geometri adalah Geometers' Sketchpad, yang merupakan salah satu bentuk 
Dynamic Geometry Software. "Geometers' Sketchpad" atau biasa di kenal dengan singkatan GSP adalah salah satu software geometri dinamis untuk dimensi-2 yang bersifat komersial. Software Geometers' Sketchpad diciptakan dan dikembangkan oleh Nicholas Jackiw. Software ini compatible untuk komputer dengan system Windows versi 9.5 ke atas dan Mac O.S versi 8.6 ke atas. GSP juga sudah dapat dioperasikan pada komputer dengan sistem operasi Linux walaupun belum sempurna.

Pada saat ini program Geometer's Sketchpad (GSP) adalah salah satu software geometri interaktif yang cukup populer. Hampir seluruh bagian dari matematika bisa dipelajari menggunakan software ini, antara lain Geometri, Kalkulus, Aljabar dan sebagainya. Program ini dirancang untuk bisa dijalankan minimal pada sistem Windows 95, Windows NT 4.0, Mac OS 8.6, atau Mac OS X. Program ini juga menyediakan animasi, memberikan kemudahan untuk menghitung panjang, mengukur sudut, mengukur luas, keliling dan lain sebagainya.

Dalam Kamus Besar Bahasa Indonesia (1991:523) konvensional artinya berdasarkan kebiasaan atau tradisional. Jadi, pembelajaran konvensional adalah pembelajaran yang biasa dilakukan oleh guru. Pada umumnya pembelajaran konvensional adalah pembelajaran yang lebih terpusat pada guru. Akibatnya terjadi praktik belajar pembelajaran yang kurang optimal karena guru membuat siswa pasif dalam kegiatan belajar dan pembelajaran

Pembelajaran konvensional yang dimaksud dalam penelitian ini adalah pembelajaran yang tanpa menggunakan alat bantu GSP. Russeffendi (2006) menyatakan bahwa pembelajaran konvensional adalah pembelajaran di mana guru mendominasi kelas, siswa pasif dan hanya menerima. Robertson dan Lang (Rusmini, 2007) menyatakan pembelajaran konvensional selain sangat berpusat pada guru juga lebih bersifat deduktif yaitu aturan dan generalisasi biasanya disajikan pada awal pembelajaran yang selanjutnya diikuti sajian ilustrasi berupa contoh-contoh soal serta soal latihan.

\section{METODE PENELITIAN}

Metode penelitian yang digunakan yaitu quasi eksperimen dengan desain kelompok kontrol tidak ekuivalen (the nonequivalent control group design). Pada penelitian kuasi eksperimen ini subjek tidak dikelompokkan secara acak, tetapi peneliti menerima keadaan subjek seadanya (Ruseffendi, 2005:52). Selanjutnya pada kelompok yang terpilih tersebut diberikan pretes, perlakukan yang berbeda, dan postes. Perlakukan yang diberikan meliputi perlakuan pembelajaran berbasis masalah berbantuan program Geometer's Sketchpad $\left(\mathrm{X}_{1}\right)$, pembelajaran berbasis masalah tanpa berbantuan program Geometer's Sketchpad $\left(\mathrm{X}_{2}\right)$, dan pembelajaran konvensional (tidak diberikan perlakuan khusus) pada kelompok kontrol. Baik pretes maupun postes berisi tes kemampuan representasi multipel matematis (O). Oleh karena itu penelitian ini menggunakan disain kelompok kontrol tidak ekuivalen seperti berikut:

$\begin{array}{lll}\mathrm{O} & \mathrm{X}_{1} & \mathrm{O} \\ \mathrm{O} & \mathrm{X}_{2} & \mathrm{O} \\ \mathrm{O} & & \mathrm{O}\end{array}$

Keterangan:

$\mathrm{O}$ : Tes kemampuan pemecahan masalah dan representasi multipel matematik

$\mathrm{X}_{1}$ : Perlakuan dengan menggunakan pembelajaran berbasis masalah berbantuan program GSP (PDG)

$\mathrm{X}_{2}$ : Perlakuan dengan menggunakan pembelajaran berbasis masalah tanpa berbantuan program GSP (PTG)

Pada penelitian ini digunakan variabel pengontrol berupa perbedaan kemampuan awal matematika siswa. Hal itu didasarkan pada asumsi bahwa setiap siswa di sekolah manapun memiliki kemampuan awal yang berbeda-beda (unggul dan asor). Variabel ini diduga mempunyai pengaruh yang kuat terhadap kemampuan representasi multipel matematik siswa. Populasi dalam penelitian ini adalah seluruh siswa kelas VII SMP $\quad 10$ Kota Tasikmalaya. Penentuan sampel. 
dilakukan menggunakan purposive sampling. Sampel penelitian diambil tiga kelas dari semua kelas VII yang ada di SMP Negeri 10 Kota Tasikmalaya. Dua di antaranya akan dijadikan sebagai kelas eksperimen dan satu kelas lainnya akan dijadikan kelas kontrol. Kelas yang menjadi sampel yaitu Kelas VII G dijadikan kelas eksperimen pertama yaitu pembelajaran berbasis masalah berbantuan program GSP (PDG), kemudian kelas VII I menggunakan pembelajaran berbasis masalah tanpa berbantuan program GSP (PTG) dan terakhir kelas VII $\mathrm{H}$ sebagai kelas dengan pembelajaraannya pembelajaran konvensional.

Instramen tes berupa soal-soal yang digunakan untuk mengukur kemampuan representasi multipel matematis. Bentuk soal tes representasi multipel matematis adalah uraian yang terdiri dari 6 butir soal. Tes representasi multipel matematik bertujuan untuk mengukur kemampuan siswa melakukan translasi dari satu jenis representasi ke jenis representasi lainnya. Misalnya melakukan translasi dari representasi verbal (kata-kata) ke representasi visual (gambar). Soal ini digunakan untuk mengetahui tingkat kemampuan representasi multipel matematis siswa setelah mendapat penerapan pembelajaran berbasis masalah. Setelah tes diberikan baik pretes maupun postes, kemudian dari hasil pretes dan postes tersebut diolah, Pengolahan data kuantitatif dilakukan melalui dua tahapan utama. Tahap pertama, menguji persyaratan statistik yang diperlukan sebagai dasar dalam pengujian hipotesis yaitu uji normalitas sebaran data subyek sampel dan uji homogenitas varians terhadap bagian-bagiannya maupun keseluruhannya. Tahap kedua, untuk mengetahui ada atau tidak adanya perbedaan dari masing-masing kelompok, terdapat interaksi atau tidak antara variabel bebas dengan variabel kontrol terhadap variabel terikat sesuai dengan hipotesis yang sudah dikemukakan, digunakan uji ANOVA dua jalur dilanjutkan dengan uji pasangan (posthoc) yaitu menggunakan uji Scheffe.

\section{HASIL DAN PEMBAHASAN}

Berdasarkan tujuan penelitian dinyatakan bahwa tujuan penelitian ini adalah untuk mengetahui perbandingan peningkatan kemampuan pemecahan masalah dan representasi multipel matematis antara siswa yang pembelajarannya menggunakan pembelajaran berbasis masalah berbantuan GSP, dengan siswa yang pembelajarannya menggunakan pembelajaran berbasis masalah dan siswa yang pembelajarannya menggunakan pembelajaran konvensional.

Hasil penelitian ini, menghasilkan beberapa temuan mengenai kemampuan pemecahan representasi multipel yang dianalisis berdasarkan kelompok atau kelas pembelajaran dan berdasarkan Kemampuan Awal Matematika (KAM) yang dikelompokkan berdasarkan dua kategori yaitu unggul dan asor. KAM diolah berdasarkan tiga ulangan terakhir dengan kriteria jika lebih dari skor rata-rata masuk ke kelompok unggul dan jika di bawah rata-rata dimasukan ke dalam asor. Berikut ini penjelasan mengenai temuan-temuan yang didapat peneliti:

Peningkatan kemampuan representasi multipel matematis siswa dihitung berdasarkan skor pretes dan postes yang telah diperoleh baik di kelas yang melaksanakan pembelajaran dengan model PDG, siswa yang melaksanakan pembelajaran dengan model PTG dan siswa yang melaksanakan pembelajaran KV. Hasil temuan menunjukan bahwa terdapat perbedaan yang signifikan peningkatan kemampuan representasi multipel matematis antara ketiga kelas tersebut. Peningkatan representasi multipel matematis terebut berbeda dikarenakan siswa pada kelas PTG lebih aktif dalam pembelajaran dibandingkan dengan siswa yang pembelajarannya menggunakan $\mathrm{KV}$. Keaktifan tersebut terlihat pada proses diskusi, dimana siswa yang berkemampuan tinggi dalam satu kelompoknya memberikan bantuan kepada siswa yang berkemampuan rendah, berbeda dengan pembelajaran konvensional yang mengandalkan proses penyampaian 
materi guru sehingga pembelajaran lebih didominasi oleh guru. Hal ini berakibat kemampuan siswa memahami materi lebih baik dibandingkan dengan siswa yang hanya diam dan mendengarkan apa yang disampaikan oleh guru. Hal ini sesuai dengan pendapat Amir, M. Taufiq (2009: 12) "salah satu metode yang banyak diadopsi untuk salah satu metode yang banyak diadopsi untuk menunjang pendekatan pembelajaran learner centered dan yang memberdayakan pemelajar adalah metode Problem Based Learning (PBL)".

Hal menarik dari pembelajaran berbasis masalah adalah adanya masalah yang dirancang oleh guru untuk diberikan kepada siswa. Masalah yang diberikan oleh guru harus mampu memberikan motivasi pada siswa agar siswa menjadi tertarik untuk belajar matematika. Hal ini dijadikan dasar karena masalah yang diberikan oleh siswa kadang dimaknai berbeda, bahkan membuat siswa menjadi tidak tertarik untuk belajar matematika.

Salah satu langkah yang dilakukan oleh peneliti adalah membuat masalah yang berkaitan langsung dengan kehidupan nyata, sehingga siswa melihat mata pelajaran matematika dari sudut yang pandang yang berbeda bahwa matematika berkaitan erat dengan kehidupan nyata. Penjelasan tersebut didukung oleh pendapat Sumarmo, (2013:385) mengemukakan bahwa pembelajaran berbasis masalah sebagai suatu model pembelajaran yang diawali dengan penyajian masalah kontekstual untuk mendorong siswa memperoleh pengetahuan dan pemahaman konsep,mencapai pemecahan masalah , memiliki kemandirian belajar, ketrampilan berpartisipasi dalam kerja kelompok, dan kemampuan pemecahan masalah. Merujuk dari pendapat Sumarmo tersebut, bahwa pembelajaran berbasis masalah memberikan sarana kepada siswa untuk menjadi pemecah masalah "problem solver". Hal ini dikarenakan siswa pada setiap kelompoknya mempunyai peranan yang sangat penting untuk dapat bekerjasama dalam kelompoknya. Berbeda dengan pembelajaran konvensional mereka tidak dibiasakan menjadi problem solver karena terkesan pembelajaran konvensional bersifat satu arah yaitu penjelasan dari guru saja.

Kebiasaan menjadi pemecah masalah tersebut membantu siswa dalam meningkatkan kemampuan represntatif multipel matematis siswa. Hal ini didasarkan karena siswa dalam kelas PTG sudah terbiasa dengan masalah yang disajikan pada bahan ajar. Hasil penelitian mengenai perbedaan peningkatan kemampuan representasi multipel matematis siswa antara kelas pembelajaran berbasis masalah dengan kelas konvensional, didukung oleh penelitian sebelumnya yaitu penelitian yang dilakukan oleh Tatang Herman pada tahun 2007 berdasarkan hasil penelitian, diperoleh kesimpulan sebagai berikut: Pembelajaran Berbasis Masalah (PBM) terbuka dan PBM terstruktur secara signifikan lebih baik dalam meningkatkan kemampuan berpikir matematik tingkat tinggi siswa dibanding pembelajaran konvensional (biasa). Namun, antara PBM terbuka dan PBM terstruktur tidak ditemukan adanya perbedaan yang berarti dalam meningkatkan kemampuan berpikir matematik tingkat tinggi siswa.

Hal menarik lain dari penelitian ini adalah adanya media pembelajaran menggunakan program GSP. Program GSP membantu siswa terutama pada materi-materi yang berhubungan dengan bangun datar di SMP, program GSP membantu pemikiran siswa dalam memvisualisasikan konsep matematika, sehingga matematika tidak terkesan abstrak dengan adanya GSP ini. Bantuan GSP membuat siswa dapat dengan mudah memahami materi sehingga kemampuan siswa dalam represnsetatif multipel lebih baik dibandingkan dengan siswa yang tidak diberikan bantuan GSP. Hal ini didukung oleh penelitian Utami (2013), yang memberikan kesimpulan bahwa peningkatan kemampuan representasi matematik siswa yang memperoleh pembelajaran berbasis masalah berbantuan GSP lebih baik daripada siswa yang memperoleh pembelajaran matematika siswa dengan pendekatan ekspositori.

Kemudian temuan lain menyebutkan bahwa siswa pada kelompok unggul peningkatan kemampuan representasi 
multipel matematisnya lebih baik dibandingkan dengan siswa pada kelompok asor, baik dikelas PDG, kelas PTG, dan kelas KV. Siswa pada kelompok unggul mereka lebih cepat memahami materi dikarenakan mereka sudah memiliki kemampuan yang baik dalam mata pelajaran matematika mulai dari operasi hitung, pecahan dan lain sebagainya, sehingga ketika mengerjakan soal yang berkaiatan dengan segitiga dan segiempat ketika mereka sudah bisa memahmai konsep mereka lebih mudah menerapkannya dalam mengerjakan soal tersebut karena kemampuan dasar matematikanya sudah baik. Berbeda dengan kemampuan siswa pada kelompok asor mereka tidak memiliki kemampuan dasar matematika yang baik seperti pada kelompok unggul sehingga mereka lebih lama memahami materi matematika karena kemampuan dasarnya itu.

Selama penelitian berlangsung, tidak selamanya penelitian itu sesuai dengan apa yang sudah direncakan, penelitian yang telah dilaksanakan ini ada beberapa kendala yang dialami. Kendala pertama mengenai waktu penelitian yang tidak cukup terutama pada pertemuan-pertemuan pertama. Siswa kurang bisa dikondisikan dalam model PTG, sehingga guru masih banyak memberikan pengarahan kepada siswa dalam pembelajarannya, hal ini berakibat waktu menjadi tidak efektif. Namun pada pertemuan-pertemuan selanjutnya siswa sudah dapat menempatkan dan memposisikan diri dalam model PTG, sehingga waktu yang digunakan menjadi lebih efektif.

Kendala lain yang muncul pada saat penelitian ini adalah siswa kesulitan dalam mengerjakan bahan ajar dan LKS secara bersamaan, kesulitan siswa dimaklumi karena siswa belum terbiasa melaksanakan pembelajaran dengan model PTG. Kendala tersebut hanya muncul pada awal pertemuan saja, karena pada pertemuan berikutnya terutama pertemuan ketiga dan seterusnya siswa sudah bisa melaksanakan pembelajaran dengan baik.
Terakhir kendala yang muncul adalah mengenai penggunaan program GSP yang menurut sebagian besar siswa program tersbut asing, bahkan ada beberapa siswa yang menyebutkan bahwa program tersebut baru bagi mereka. Hal ini dimaklumi karena guru yang biasa mengajar jarang menggunakan program GSP. Namun berkat bantuan dari peneliti, peneliti mengambil inisiatif untuk membawa rekan dalam hal penggunaan GSP terutama dari pertemuan ke-satu samapai dengan pertemuan ke-tiga. Hal ini dimaksudkan agar siswa sudah bisa memahami program GSP secara menyeluruh

\section{SIMPULAN}

Berdasarkan hasil analisis, temuan, dan pembahasan mengenai peningkatan kemampuan pemecahan masalah dan representasi multipel matematik siswa melalui penerapan pembelajaran berbasis masalah berbantuan GSP (PDG), pembelajaran berbasis masalah tanpa bantuan GSP (PTG), dan pembelajaran konvensional (KV), diperoleh beberapa kesimpulan sebagai berikut: 1) terdapat perbedaan yang signifikan peningkatan kemampuan representasi multipel matematis siswa yang memperoleh pembelajaran PDG, siswa yang memperoleh pembelajaran PTG, dan siswa yang memperoleh pembelajaran KV, 2) peningkatan kemampuan representasi multipel matematis siswa unggul dan asor yang memperoleh pembelajaran PDG lebih baik dari pada siswa yang memperoleh pembelajaran $\mathrm{KV}, 3$ ) Peningkatan kemampuan representasi multipel matematis siswa unggul dan asor yang memperoleh pembelajaran PTG lebih baik dari pada siswa yang memperoleh pembelajaran $\mathrm{KV}$, 4) peningkatan kemampuan representasi multipel matematis siswa unggul dan asor yang memperoleh pembelajaran PDG lebih baik dari pada siswa yang memperoleh pembelajaran PTG. 


\section{DAFTAR RUJUKAN}

Amir, M. T. (2009). Inovasi Pendidikan Melalui Problem Based Learning. Jakarta: Prenada Media Group.

Amri, S. dan Iip K. A. (2010). Proses Pembelajaran Kreatif dan Inovatif dalam Kelas. Jakarta: Prestasi Pustakaraya.

Hudiono, B. (2005). Peran Pembelajaran Diskursus Multi Representasi terhadap Pengembangan Kemampuan Matematik dan Daya Representasi pada Siswa. Disertasi SPs UPI. Bandung: Tidak Diterbitkan

Hutagaol, K. (2007). Pembelajaran Matematika Kontekstual Untuk Meningkatkan Kemampuan Representasi Matematis Siswa Sekolah Menengah Pertama. Tesis SPS UPI Bandung: Tidak Diterbitkan

Kemendikbud. (2013). Konsep Pendekatan Scientific Diklat Guru Dalam Rangka Implementasi Kurikulum 2013, Diterbitkan Oleh: Kementerian Pendidikan Dan Kebudayaan

Lam, T. T. (2007). Use of Geometer's Sketchpad (GSP) to Teach Mechanics Concepts in A Level Mathematics. [Online]. Tersedia: http://www.any2any.org/EPATCM/ EP/2004C141/fullpaper.pdf.[10 Desember 2013].

National Council of Teachers of Mathematics (NCTM). (2000). Virginia Principles and Standars for School Mathematics. Reston VA: The National Council of Teachers of Mathematics Inc

Rusmini. (2007). Meningkatkan Kemampuan Penalaran dan Komunikasi Matematik SIswa SMP melalui Pendekatan Pembelajaran Kontekstual Program Berbatuan Cabri Geometri. Tesis UPI Bandung: Tidak diterbitkan.

Russeffendi, E.T. (2005). Dasar-Dasar Penelitian Pendidikan dan Bidang Non Eksakta Lainnya. Bandung: Tarsito.
Shadiq, F. (2004). Pemecahan Masalah, Penalaran dan komunikasi. Disampaikan pada Diklat Instruktur/Pengembang Matematika SMA Jenjang Dasar di PPPG Matematika. Yogyakarta : Tidak Diterbitkan

Siregar, N. (2009). Studi Perbandingan Kemampuan Penalaran Matematik Siswa Madrasah Tsanawiyah Kelas yangbelajar geometri Berbantuan Geometer's Sketchpad dengan Siswa yang Belajar tanpa Geometer's Sketchpad. Tesis SPs UPI Bandung: Tidak Diterbitkan.

Stepein, Word. (2000). Pembelajaran Berbasis Masalah. Tersedia [Online]: http://modelpembelajarankooperatif. com/2012/08/pembelajaranberbasis-masalah-pbm_25.html [10 Desember 2013]

Sumarmo, U. (2013). Berpikir dan Disposisi Matematika serta Pembelajarannya. Bandung: Jurusan Pendidikan Matematika FPMIPA UPI

Suryadi, Didi (2013). Eksplorasi Matematika Pembelajaran Pemecahan Masalah. Jakarta : Karya Duta Wahana.

Suryadi . (2013). Strategi Pembelajaran Pendidikan Karakter. Bandung: Remaja Rosdakarya

Utami, Amalia Fikri. (2013). Penerapan Pembelajaran Berbasis Masalah dengan Menggunakan Program Geometrer's Skechpad untuk Meningkatkan Kemampuan Pemecahan Masalah dan Komunikasi Matematika Siswa SUP. Tesis UNNES: tidak diterbitkan.

Villiers, M. D. (1998). A Sketchpad Discovery Involving Triangles and Quadrilaterals. [Online]. Tersedia: http://www.math.umt.edu/tmme/ vol4no2/TMMEvol4no2_pp.188_19 2_SA.pdf. [10 Desember 2013]. 